Abstracta Iranicacta Iranica

Revue bibliographique pour le domaine irano-aryen

Volume 40-41 | 2019

Comptes rendus des publications de 2017-2018

\title{
Javier Alvarez-Mon. “The Elamite Royal Orchestra from Madaktu (653 BC)"
}

\section{Yasmina Wicks}

\section{(2) OpenEdition \\ 1 Journals}

\section{Electronic version}

URL: http://journals.openedition.org/abstractairanica/49133

DOI: 10.4000/abstractairanica.49133

ISBN: 1961-960X

ISSN: 1961-960X

Publisher:

CNRS (UMR 7528 Mondes iraniens et indiens), Éditions de l'IFRI

Electronic reference

Yasmina Wicks, "Javier Alvarez-Mon. "The Elamite Royal Orchestra from Madaktu (653 BC)"', Abstracta Iranica [Online], Volume 40-41 | 2019, document 41, Online since 30 October 2019, connection on 16 April 2021. URL: http://journals.openedition.org/abstractairanica/49133 ; DOI: https://doi.org/10.4000/ abstractairanica. 49133

This text was automatically generated on 16 April 2021.

Tous droits réservés 


\title{
Javier Alvarez-Mon. "The Elamite Royal Orchestra from Madaktu (653 $\mathrm{BC}) "$
}

\author{
Yasmina Wicks
}

\section{REFERENCES}

Javier Alvarez-Mon. “The Elamite Royal Orchestra from Madaktu (653 BC)”, Elamica 7, 2017, p. 1-34

1 Amongst the numerous depictions of Elamites in Neo-Assyrian reliefs are two slabs from Sennacherib's Southwest palace at Nineveh illustrating the royal Elamite orchestra performing at the city of Madaktu upon the arrival of Ummannigaš/Humbannikaš II, the Elamite puppet king installed by Ashurbanipal after his defeat of the prior king, Te'umman, at the Ulai river battle in $653 \mathrm{BCE}$. Carved around $650 \mathrm{BCE}$, the scene belonged to a much larger propaganda series dedicated to Elam's defeat and submission distributed between this palace and Ashurbanipal's North palace.

2 Here Álvarez-Mon introduces the relief and offers a detailed iconographic analysis of the instruments (angular harps, double pipes, a drum, clapping and vocalization) and the twenty-six orchestra members, including a commentary on their gender identity. He observes that the meaning of the scene has been subject to a range of different interpretations, some betraying misunderstandings of its historical context, and argues that the relief-indeed the entire narrative series-must be set against a long history of Elamite interference in Ashurbanipal's geopolitical aspirations. Taking the orchestra slabs in conjunction with the North palace panels where corpses of Elamite soldiers, horses and military paraphernalia float past in the river beside the installation ceremony of the puppet king, accompanied by an absurd caption proclaiming his "joyful" entrance into the city, Álvarez-Mon argues that we are looking at a visually 
entertaining and "superbly crafted portrait of Ummanigaš' humiliating appointment as puppet ruler".

3 At the conclusion of the article, we are presented with the possibility that Elamites had been amongst the textually attested groups of foreign musicians in the court at Nineveh and an interesting proposal as to who may have been responsible for vandalising the garden relief in the North Palace-clearly an "inside job"!

\section{AUTHORS}

\section{YASMINA WICKS}

Department of Archaeology, The University of Sydney 